\title{
An Analysis of Big Data Analytics, IoT and Augmented Banking on Consumer Loan Banking Business in Germany
}

\author{
Maulibian Perdana Putra \\ LSPR Communication and Business Institute. Jakarta, Indonesia
}

\begin{abstract}
This research aims to analyze the particular component of industry 4.0 applying in the consumer loans banking business. Industry 4.0 comprises of a lot of technological advantages, this research selected three components of industry 4.0; Big data analytic, Internet of Things (IoT), and Augmented reality in banking. Secondary data are used to conduct this research, collected from the previous research and the academic literature. At first, this research explains why the consumer loans banking business in Europe, especially in Germany, needs to integrate Industry 4.o. secondly, this research analyzes the suitable component of industry 4.0 into the consumer loans banking business. The findings of this research deliver an essential piece of analysis to the consumer loans banking business' stakeholder with direction on implementing industry 4.0 into their business.
\end{abstract}

Keywords: Industry 4.0; Consumer loans; Big data analytic, Internet of things, Augmented banking

\section{INTRODUCTION}

As general banks, main revenues are coming from two different sources of loans. The first is from the corporate banking loans, which deal with the big corporation and international finance. The second comes from the commercial banking loans in which dealing rather with the personal, retail and small to medium size of business. Those two different sources of revenue also weighting the same importance for both bank and for economics point of views. Thus, many large and international banks incorporate both commercial banking and corporate banking into their own business lines (Finlay, 2008).

Consumer loans as a part of the commercial banking not only contributes positively to the individual and household but also to the sellers of good and services. Moreover, a healthy consumer loan becoming the pushing factors of economic growth. However, when the consumer loans become dispute and the people cannot pay their loan according to the contract and agreement it also will harm society and the economics. In Euro areas the loss and detriment occur from consumer loans are high and its counted as the one of most financial detriment in all business market, with approximately 12 billion Euros loss in 2016 higher than the loss from others business such as mobile telephone services, electricity, train services, and clothing (including bag and footwear) business (Financial Services and User Group, 2019; Commission, 2017).

In addition to that, consumer loans industries were also facing legitimate competition from the new emerging market of Fintech industries. The Fintech industries possess disruptive 
innovations towards the consumer loans business as they also serve and provide similar product and services (Christensen, 1997).

This research aims to deliver strategic and systematic analysis of the consumer loans banking business with the integration selected component of industry 4.0. Industry 4.0 comprises a lot of things in regards of advanced technology being used in order to create more value for the company. For the purpose of the research not all the industry 4.0 elements could be applied to the consumer loan banking business. The first objective is to determine why the consumer loan banking business need the technological advantages of Industry 4.0, the next objective is to analyze the business-related situation that could occur when applying the selected component in Industry 4.0 into the consumer loan banking business.

Those aims will fulfill by accomplished the following main criteria of research questions: (1) provide and describe the consumer loans industries and the relevant information behind the business; (2) providing the general overview about the Industry 4.0 technological advancement of big data analytic, IoT and augmented banking; (3) analyze the factor and the reason behind why consumer loans banking business need industry 4.0; and (4) analyze the three component of Industry 4.0 of big data analytic, IoT and augmented banking when applying and integrate into the consumer loans banking business.

\section{Consumer Loan}

Consumer loan is a formal financial commitment legally binding by the contract to create a relationship between the lender (the creditor) and the debtor, one big critical point to underline in consumer loans is the type of debtor, which are the individual (Finlay, 2008). One party will act as a lender/creditor to provide funds in forms such as cash, goods, or services to another party - borrowers/debtor, who undertake a binding contract as a commitment to repay the debt at some point in the future (Finlay, 2008). Furthermore, the authority, such as European Banking Authority, defines consumer loans as the loans for the primary use for individual consumptions of goods and services, and other loans such as business and educations (EBA, 2019).

Consumer loans clear definitions are considerably broad, on the dictionary of baking and finance (Collin, 2003) state consumer loans are a credit given by the merchant, shop, bank to the costumer to enable them to buy the goods or services. The oxford dictionary of the dictionary of finance and banking (Smullen \& Hand, 2005) emphasized the duration of consumer loans as "short term lending to the public" it is somehow insufficient as the phrase of short term not being fully elaborate the definite meaning (Finlay, 2008). Another research also underlines the time period of consumer loans, consumer loans are the loan that including short and intermediate period of loan that can be for costumers finance their personal consumption of the commodities and service (Malhotra \& Malhotra, 2003). The growth rise and growth of consumer loans will also affect and stimulate the growth of individual household consumptions (Vasileva, 2019). Thus, consumer loans are becoming an essential tool for macroeconomic policies.

Many researches pointing out the more restricted definitions of consumer loans, in particular, a credit that are being back-up by the mortgages are being classified into another category different than consumer loans, these specific definitions characteristic on the consumer loans are important and need to be emphasized for the purpose of this research "consumer loans as 
an unsecured loans". Unsecured means that the credit took by the debtor are not guaranteed by mortgages and usually used by the households to pay the goods or service that they are unable or unwilling to pay immediately at full price. (Finlay, 2008). Another research journal also stress about the exclusive meaning of the consumer loan as unsecured loans, consumer loans are being refers as the money loan to personal, family or household use, such loans are not secured (He et al., 2015), the money used today are being as an exchange for the promise of repayment in future (Parlour \& Rajan, 2001). Without the backup on loan by asset provided by the debtor, unsecured loans carry a relatively high risk to the lender; therefore, in order to mitigate risk arise within the loan, lenders tend to cap their maximum nominal of their unsecured loans (Finlay, 2008). Furthermore, the purpose of the research will focus on the unsecured consumer loans and with the debtor are the individuals in which the responsible of the credit lies within the individual, should be traceable and not some company or others institution.

In consumerism culture, is not hard to find credit transaction occurring in everyday life and an option to buy any goods or services through installment or some others form of credit also available, therefore even though people are not capable of paying full time at the moment in time for their desire goods or services, through credit or installment, purchasing good becomes possible. It's no surprise that consumer credit has become such a huge business. From a macroeconomics standpoint, the better economic condition will also make consumer loan growth. With the improvement and good economic condition, consumers expected to not delay and hold their consumption of the goods and services (Mazibaş \& Tuna, 2017). In the Europe Market, consumer loans also growth relatively stable from 812 billion in 2013 to 921 billion in 2017, which also worth noticing the increasing the number from 2016 to 2016 by 5.1 \% (figures 1)

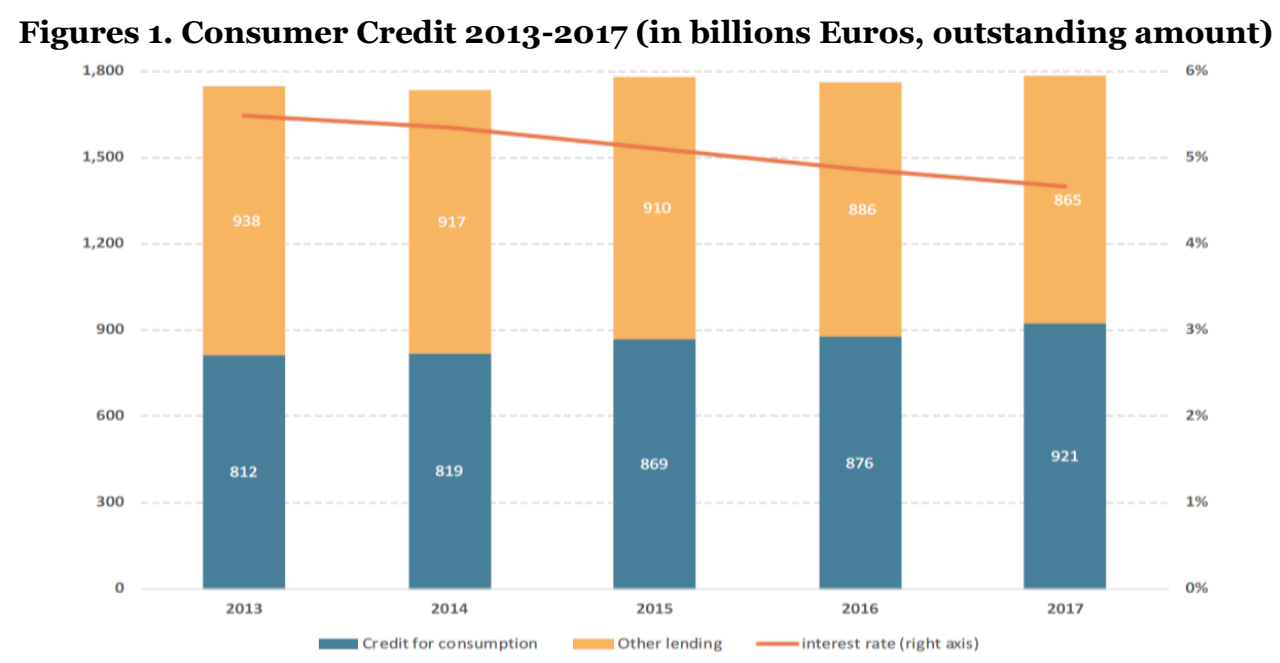

Source: EBA Consumer Trend Report (2018/19)

As Figure 1 shows, the outstanding of consumer loan credit in Europe has been relatively stable with a constant increase from 2013 to 2017. The reasons for this trend are because some European Union (hereafter refers to EU) country decreased their interest rate for consumer loans (EBA, 2019). In line with the trend, the ratio of outstanding of the consumer loans compares to the others loans also showing the same number of results of past 5 years from 2013 to 2017 as shown in figures 2. 
Figures 2. Consumer loans to all loans

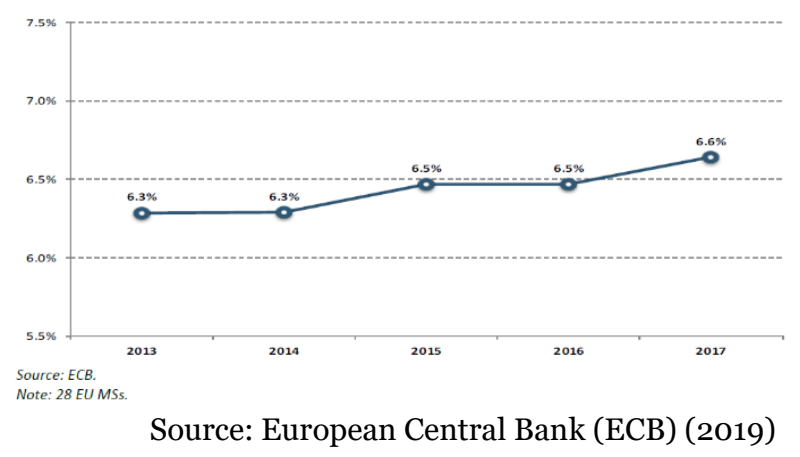

Although the total outstanding of consumer loans are considerably low to the total outstanding loans in Europe in comparison, when the consumer loans become default because of the misused, the effect is still being able to harm the customer and create detriment for the borrowers. Unhealthy consumer loans will become a debt burden and create instability financial conditions, these instability conditions will expose the costumer to others disadvantages such as social exclusion and physiological and health issues (EBA, 2019).

In Germany, the growth of consumer loans also relatively stable, the total amount of consumer loan to an individual in the half-year of 2019 is approximately 1.254 million Euro. Compare to only 871.4 million Euro 20 years ago in 1999 as shown in figures 3 .

Figures 3 Amount of loans to private and individual in Germany

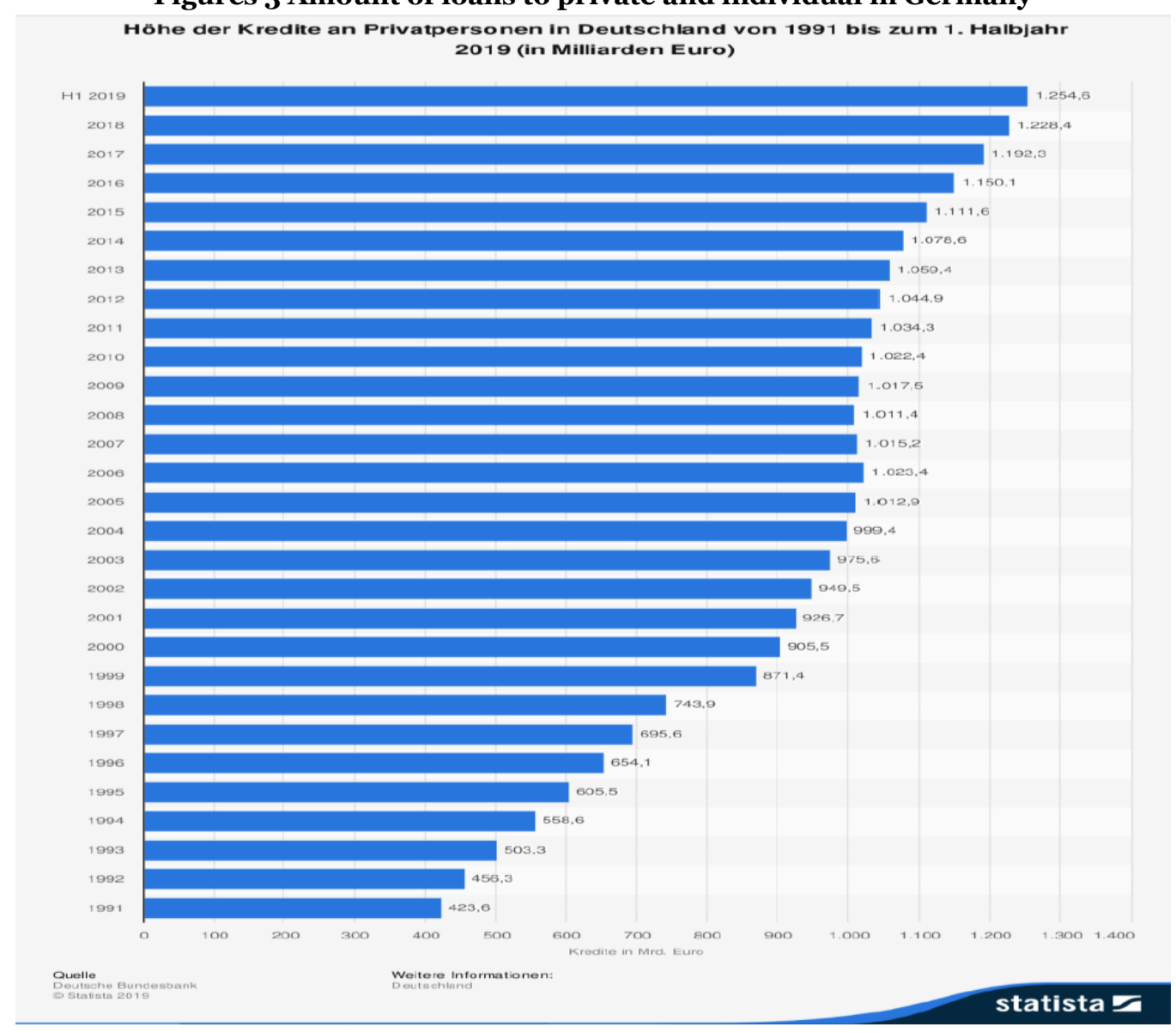

Source: Statista (2019) 
Market in Germany indicates that banking industries have significant rules and create a banking-based condition for the financial market, not only for the private and individual are depend on the bank, the big firm and Small Medium Enterprises (SME) also mainly use the bank as their financial resources. Bank loans consider the most important external source financing the firm, with approximately $20 \%$ of external debt in average firm in Germany (Schmidt and Zwick, 2018). The special connections between the firm and the bank lead the Germany's banking industries classified into three different categories: first is the private or commercial bank, second are the public saving bank, and the third is the cooperative bank (Koch et al., 2016).

With large number in the Germany banking, the competitions on the consumer loans market are high; therefore the rates or the prices of the products and service are in competitive price (Koch et al., 2016). Another point worth noting is the German banking business is the dependency of Germany's bank on the net interest income due to the cultures of the customers that avoided the fee charges, and thus makes the bank loans market in Germany are competitive. The data shows that net interest income is about $70 \%$ of the total operating income in Germany's banking market (average from 2000 - 2013). Loans business, especially consumer loans, are continually growing the German market and remaining as a profitable competitive business (Koch et al., 2016).

Another important fact of consumer loans in Germany is Germany's bank structure still depends a lot on the brick and mortar banking service. It means that if somebody needs the service and product of the bank, they tend to go to the nearest banking breach. Germany bank still maintains the high branch density, by the end of 2013 recorded with over 36.000 branches in total. It's considered to be a high number, Germany has approximately 416 branches per million people, at the other hand western Europe only have an average of 387 branches per million people and UK with just 179 branches per million people (Koch et al., 2016). This indicates that a huge amount of investment has been made into banking industries and this investment also exposes to the big risk from technological distribution from new fintech business.

Moreover, this brick and mortal way of business is also affected Germany's bank in financial level. According to Koch et al. (2016), cost-to-income ratio in German banking business are relatively high from 2010 until 2013 even compare to the other countries (figures 4).

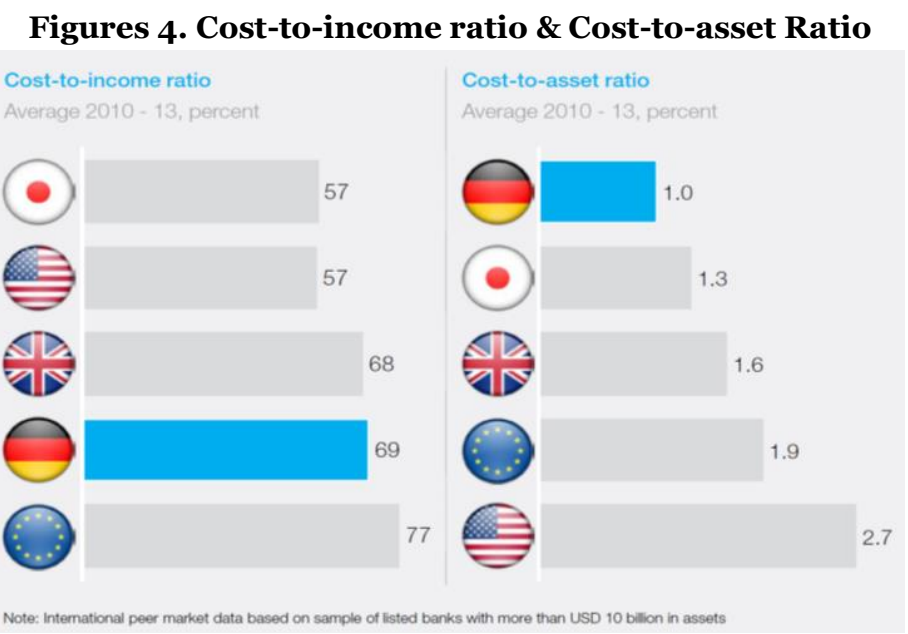

Source: Koch et al. (2016) 
The percentages in figures 4 indicate that with $69 \%$ in the cost-to-income ratio, Germany's banking business is relatively worst compared to UK or Japan. These numbers rise because of the consequence on Germany's banking characteristic with the large asset-based. Although being highly cost and low profitability, Germany's banking business still able to become efficient in the operational level due to the efficient payment system and operational efficiency (Koch et al., 2016).

\section{Industry 4.o}

The term of industry 4.0 introduces first in Germany in 2011 (Kagermann et al., 2013), it is an industrial revolution caused by technological development and enables the transformations in the manufacturing industry. In much technological and practical terms, the German Federal Government through the Deutsch Kommision Elektrotechnik, German industrial associations and together with the German standards organizations, present the standardization definition of industry 4.0 as "High-density networking of all objects over the whole life cycle of the product. In other words, from its conceived by engineers, via its production, right through to the end of the product life cycle, after which an object is disposed of or recycled" (Adolph et al., 2018). Although in the beginning, the term Industry 4.0 is limited only to the manufacturing industry but nowadays any other field of the industry also adopt the idea of industry 4.0 and integrated into their business model.

Industry 4.0 is growing interdependence on the business world, involving almost all of the players, including customers, producers, suppliers and government. The fundamental element and also act as the main drivers of Industry 4.0 o are the use of advanced technology such as robotics, autonomous, addictive manufacturing, Internets of Things (IoT), advanced mobile communications $(5 \mathrm{G})$, sensor, system integration, Cloud, big data, data analytic and simulation, therefore enable to increased productivity diversity and lower costs achieved through optimization and smart productions techniques (Gunal, 2019), enable to help and transform the isolated cell into optimized, fully integrated and automated production flow. In addition to that, Industry 4.0 also able to make the company to have complete control on the value chain of their product and services business lines (Vaidya et al., 2018).

Impact of industry 4.0 are significant and massive, in Germany alone where are the industry 4.o begin to develop, Rüßmann et al (2015) a research team in Boston Consulting Group point out that industry 4.0 contribute about 1 percent per years into GDP over ten years period and able to create approximately 390.000 new job, and also adding 250 billion Euro investment in manufacturing sector equals to 1 to $1.5 \%$ percent of manufacture's revenues.

\section{Big Data and Analytics.}

Big data and analytics refer to the collections and comprehensive evaluations of data from many different sources (Rüßmann et al., 2015), such efforts been made to provide and help decisions making process in order to generate positive value to companies (Gobble, 2013), hence the improvement of the competitive advantages of the company will be achievable. The positive result of using big data analytics research describe by Lozada et al. (2019) are the direct relationship between the big data analytic and the co-innovation, through big data analytics all the stakeholder in the business are able to enhance and strengthen the 
collaboration and communications process better in which are the important factor to create the co-innovation.

Moreover, the use of big data analytics enables the company to be aware and analyze the environment and gather all the available valuable information in order to enhance the novelty factor and quality of the new product and service (Seddon \& Currie, 2017). There are seven concepts of big data analytics that have been identified so far by the researcher in order to identify the main challenges (Lozada et al., 2019).

The first characteristic of big data is volume, this characteristic refers to the data size, in the big data analytics case, those data are collected continuously and will grow to a remarkable level. Thus, exposing the problem of data storage, acquisition and processing (George et al., 2016). The second characteristic is a variety of the data, in what form are data being generated - audio, video, text, images thus, challenges arise in the heterogeneity of the data (Lozada et al., 2019). The third characteristic is related to the velocity inside the data process, how are the data still have a value when it is being up-to-date and the value of data will gone when it is already out-of-date (George et al., 2016; Lozada et al., 2019). The fourth characteristic of big data is the quality, it speaks about the accuracy of the data and also the reliability of the sources. The fifth characteristic are the visualization, how the gathered data are being able to visualize and able to be presented (Seddon \& Currie, 2017). Sixth attribute are related to the value of data, big-data are able to contribute positively to the users through the valuable information inside the big data analytic (Sivarajah et al., 2017). Seventh and the last variable is the variation of the data, it refers to the data interpretations, it is possible one same data being interpret differently at a different time or by different users (Seddon \& Currie, 2017; Sivarajah et al., 2017).

The resources of the data also are being important when talking about big data analytics. Gupta and George (2016) describe there are three categories of resources on the literature that being accountable related to big data analytics. First are the tangible and infrastructure resources, it is important to determine the origins and the nature of data as well as the infrastructure that is built around the data. Second characteristic are the human resources, in this characteristic the are two different groups; the first groups are the people who have the ability to and possess technical skill on the big-data such as programming, data mining, artificial intelligence, machines learning and also the recent advance technology related to the big-data. The second group are the people who has the managerial skill, it refers to the ability and capability translate the big-data into somewhat meaningful and positive impact on the different field of the company. The third characteristic of the resources are the intangible resources. Intangible means that there are not exact and noticeable borderline and the value of the data depend on the users. While most intangible resources cannot be trade or sold there are however some intangible resources that able to be sold and trade such as patent, copyright, trademark. 
Figures 5. Classifications of big data resources

\begin{tabular}{|c|c|c|}
\hline \multicolumn{3}{|c|}{ BIG DATA ANALYTICS CAPABILITY } \\
\hline TANGIBLE & HUMAN & INTANGIBLE \\
\hline $\begin{array}{l}\text { Data } \\
\text { (internal, external, } \\
\text { merging of internal } \\
\text { and external) }\end{array}$ & $\begin{array}{l}\text { - Managerial Skills } \\
\text { (analytics acumen) }\end{array}$ & $\begin{array}{l}\text { Data-driven Culture } \\
\text { (decisions based on } \\
\text { data rather than on } \\
\text { intuitions) }\end{array}$ \\
\hline
\end{tabular}

\section{Internet of Things (IoT)}

Even though the internet is already being develop and used a lot even from last decade, it still undergoes the changes and Internet of Things hail as the first evolutions of internet. The general definitions of Internet of things according to CISCO Internet business solutions group (IBSG) are when the things are being connected to the internet and reach the point where the numbers are larger than connectivity between human and internet (Evans, 2011). There are slightly misunderstand concept about the IoT are being the same with the World Wide Web or Web, people are being confuse by the meanings of both and use it interchangeably even though fundamentally they are different, to put it simple internet are the network that being use to transfer information securely, efficient and reliable made-up by technological equipment such as router and switches. On the others hand Web are the applications that being used to help and stabilize the information flow of the internet by providing a reliable interface (Evans, 2011).

In the business world, through IoT all the components on the supply chain management are being connected using the technology. Machines and sensors in manufactures are being connected vertically and horizontally in order them to communicate and interact each other, also through connection with both centralize operations system and decentralize analytic will enable the real-time decisions making (Rüßmann et al., 2015).

\section{The Need of Industry 4.0 in Consumer loans}

It is in the common knowledge that the use of technology is indispensable to business world, the high complexity demands of costumer create a massively pressure. In consumer loans business are no different, bank need to be adapted into the costumers demands for more convenient and fast respond services and product. Digitalization will be key factor for banking business, bank must able to get benefit and survive in the rapid development of technology. This chapter will explain more and comprehensive answer about the importance of using the currents technological developments in form of Industry 4.0.

\section{Consumer loan detriments}

Consumer loans rates or prices mostly set by regulator, this happen because interest rates are part of the monetary policies and also others variable such as investment rate and inflations should be taken into considerations. Regulator increase or decrease the interest rate depend 
on the macroeconomics situations, interest rates have a tendency to be decrease or low if the government want to increase the consumption and investment (Mazibaş and Tuna 2017).

In such market where price is relatively same, a good service will play the role. On the contrary, in the consumer loans business the service given to the costumer is one of the least unsatisfied services and also part of the highest consumer detriment of all service as the research conduct by the European commissions in 2017. (Civic Consulting, 2017).

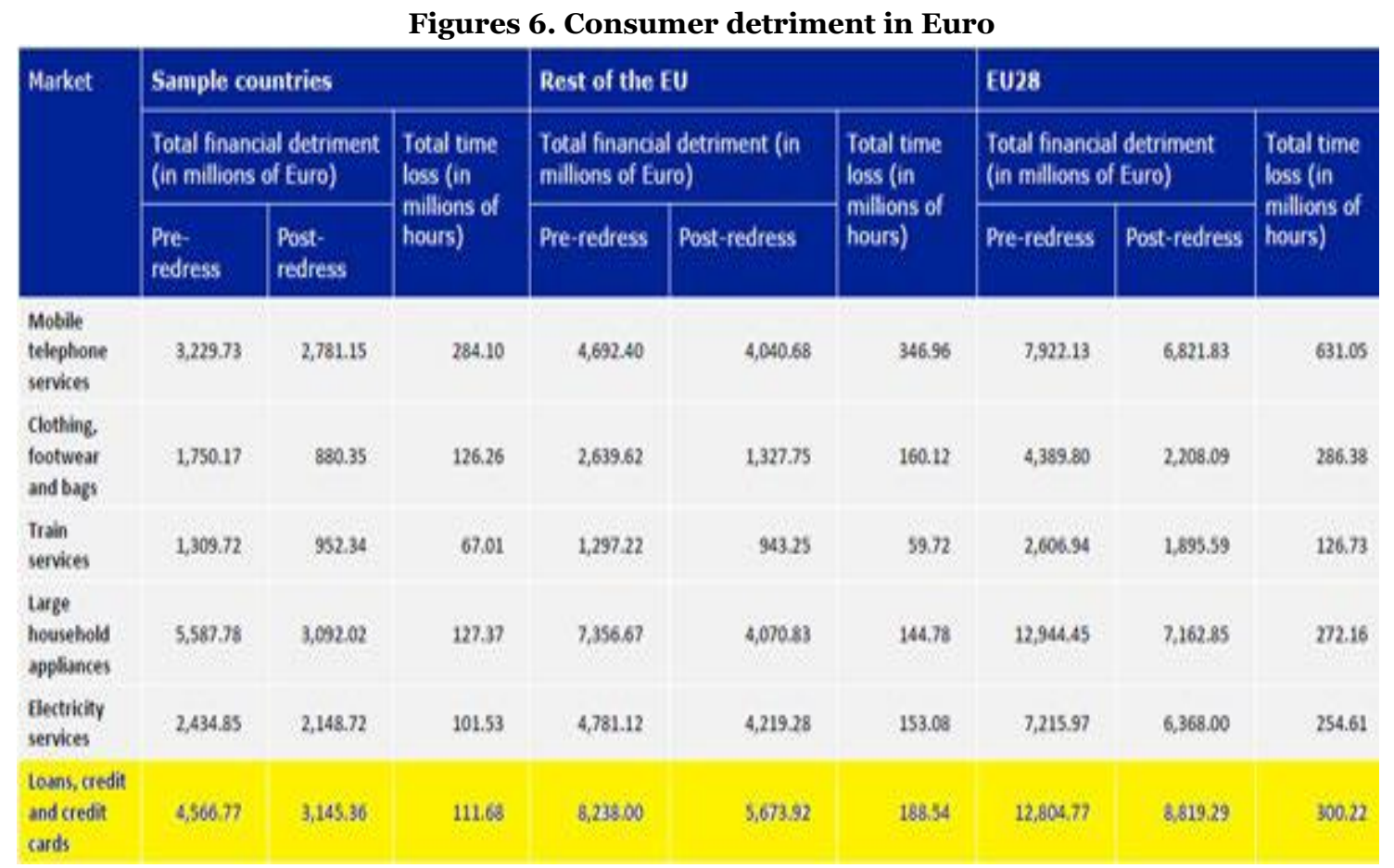

Source: European Commission (2017)

During this period, a report from every EU country by their own national competent authority and collected together by EBA says that the total financial detriment related to consumer credit was 12.8 billion Euros. It is one of the highest detriments in all industry that being reported, come in second place with only slightly different margin to the "large household appliance". The sample country on the first column France, Italy, Poland and UK.

The report shows, total amount of all complaint reported by the survey in 2017, on average $17 \%$ related to consumer loans. The top level of compliant were related to fee based, various issue related to the pre-contractual and contractual information, debt and collections, interest rate level and management issues (EBA consumer trend report, 2018/19).

A well functioned consumer loans market will create benefits to households, manufacture firm, seller, supplier and stimulates the positive economic growth within the country, but if credit become default cause miss-selling and miss-information can harm costumes, not only on the financial level but also social exclusion and psychological and health problem (Financial Services and User Group, 2019). On the macroeconomics point of view and as the integral part of monetary tools on macroeconomics level, a high number of consumer detriment in consumer loans may lead to the high level of unpaid loans (non-performing loans), the unsatisfied debtor may end up not paying their loan on-time, thus endanger the stability of financial institutions, lower the economics growth and drive the economic into recession. 
One beneficial factor that causing the high number of complain in consumer loans business are the misunderstanding and miss-information cause by the consumer in regards of using the product and service (EBA, 2019) . Consumer may not completely understand the important matters related to the loans. This matters also arise when bank using the external parties as their marketing tools, the external parties will solely focus on the result and the information about the product and service will not be their priority to accomplish.

On the EBA (2019) some national authority reports that the pre-contractual information about the loans are being insufficient, as the lack of information concerning the term and conditions, penalties and early repayment being provided by the financial institutions. Thus, Industry 4.0 through the digitalization will play the main role to bridge between the consumer and the banks. Strengthen the connections between consumer and banks through various digitals channels will revitalize bank image and enhance the user experiences for better services.

\section{Threat from the new emerging market of Fintech industry}

Form by the abbreviation of financial and technology and also refers to companies that using the up-to-date technology to operate a business model for financial service in which outside the traditional model, seeking a way to improve how these service offered (International). As a rule the new participant or start-ups aim to gain and attract costumer by offering the services and products that are more user friendly, efficient, transparent and automated than those currently available in the market through optimizing the internet-based and applications oriented products (Dorfleitner et al., 2017; Milian et al., 2019)

According Christensen (1997) the theory of disruptive innovation can be classified into two categories. First is the "sustainable players". The establish financial service providers who using the innovations for maintain the hegemony and protect their market positions. The second are the "disruptive players", the new companies challenges the big established players offering new kind of product and service. This part of research will explore more on the second disruptive cause by new fintech companies on the traditional establish banking business.

In February 2016, a total of 436 fintech company offering product and service in Germany were identified, the Germany Fintech market thus ranks in second behind the UK within Europe (Haddad \& Hornuf, 2019) particularly in Berlin, Munich, Frankfurt and Hamburg. Market size-wise in 2015, total volume of the Fintech Market in Germany in the financing and wealth management segment was 2.2 billion Euros and approximately 1.2 million Germans used the interdependent personal management system to manage their personal finance (Dorfleitner et al., 2017).

According to the Gomber et al. (2017) there are three main reason why digital fintech companies could be endangering the traditional consumer loan banking business model. First, fintech companies could offers new product and service that be a solution and solve the need of the costumer that cannot be provide or sufficiently available by traditional consumer loans banking service and products. Second, fintech companies able to create their own opportunities for the business sales with the use of new advance technologies and new concept, create the new channel that could be broader the marketing tools compare to the traditional consumer loans banking business. third, the working culture of fintech companies tend to be agile and innovative, focus on the internet-based business model and the accessibility of the 
products and services and it's essentially different to the traditional bank and financial services provider.

\section{METHODOLOGY}

The research used secondary data as a primary resource to provide research objective. These secondary data collected using published journal literature as well as the academic literatures. Journal literature used for this research mostly have a relevant academics problem related to the topics gathered through digital library and trusted online journal publication including Business Source Premiere, Springerlink, Statista, Science Direct, and Bisnode Firmenprofile. Many research has been undertaken in the term of industry 4.0, but majority are towards the manufacture business. Industry 4.0 mainly related to supply chain management, moreover in the early development of industry 4.0 are indeed designated to make supply chain management more efficient and cost saving. This reserach trying to explore another part of industry 4.0 that could be applicable in different business field especially in the consumer loans business.

The theoretical background was collected from previous research, journals as well as the academic literatures. Not only from the previous funding that related to the subject and the topics of the research, but also from the different areas and business background. In additions to that the relevant information to complement research objective was collected from organization and authority institutions including European Banking Authority, Financial Service User Group, European Commissions, McKinsey \& Company, World Bank, International Monetary Funds, scientific online article and as well as from the laws and regulation in Europe and Germany. This research has engaged both quantitative and qualitative approach to answer the research questions and relate to the research topics and the issues that being undertake.

Quantitative data was gathered to provide the pictures of consumer loans in number both in Germany and in Europa Unions, financial statistic, and also the countries indicator such as Gross national product and gross national income. Moreover, the quantitative data also being gathered to support and tell the stories about the current consumer loans business circumstance. Lastly, this research also gather data related the emerging fintech market by number in Germany.

Qualitative analysis being conduct to provide the comprehensive and systematic analysis on the consumer loans industries when applying the selected industry 4.0 components on consumer loans, furthermore this research also uses the value chain analysis to determine the Industry 4.0 components influence on the consumer loans business.

\section{RESULT AND ANALYSIS}

\section{Big data analytic in consumer loans}

Big data analytic play a big role in the consumer loans banking business. To begin with this research would discuss about the big data that already in possessions by bank first. One of bank main advantages compare to the other financial institution were the big collection data 
about their own costumer in their data base. These data collected throughout the service and product provided by the bank to costumer such as saving, investment and other loans. The collected data in consumer loan help the bank to understand the business better than others financial institutions in which did not have database as much as bank had.

From the previous finding, it is already known that industry 4.0 consist of many different technological advance factors, this chapter will analysis the effect of big data analytic. Especially how the bank will be able generates the positive outcome of the big data collections of costumer and how can they do it. Murati et al. (2018) explain that bank should leveraged their advantages of possessing big database into a stable possession where they can achieve strongest preposition. With the big database bank are expected to know better about the their environment and able to include the analysis about their costumer to into their data-driven decisions making process (Lozada et al., 2019; Sonntag et al., 2019).

The database analytic on in the consumer loans would give the banks sharper insight about their costumer and create understanding about the consumer needs. The big data analytic not only about the costumer info, but also spread widely in other term such as data about costumer preferences and costumers schedule of payment in loans. With this knowledge of the costumer, bank able to classify the costumer based on their risk profile in order to knowing which costumer prudent and which ones are with the higher risk. The understanding become important because the one of biggest risk on the consumer loans are the loss generated by debt that being written off because the consumer becoming a default, this means the consumer did not have ability to repay the loans anymore (Finlay, 2008; Bolt \& Humphrey, 2015).

One of characteristic about the big data analytic in which describe by George et al. (2016) in which relevant to this research findings is the velocity, in this context refers to the data being avoid becoming obsolete. Therefore, the importance of having an up-to-date database will play the vital point. Banks should be able gather the update costumer data base on regular basis, by doing this method early-warning systems on the consumer loans could be create through the constant update, therefore give the banks valuable information in regards of their consumer loans account. For example, an update such as marital status from single to marriage will give information to banks that specific costumer have a possibility will move into higher risk on the loans account as being marriage might possible add more expenditure on costumer, it is not always the case but having this understanding would help banks by given value of the data. Thus, enable bank to set their early-warning system where are the specific changes occur in costumer. It should be in our consideration that there are many other criteria that banks can set upon regarding the update of the costumer data not only focus on one the specific parameter, therefore applying this method would help bank to aim reducing the number of default account on their consumer loans business. To be able maximize it, a good costumer management will be necessary needed.

Another point worth noting on the importance of big database are for future reference. A prediction based on bank's database will able to predict when are the costumer need a loan most. With this sharper insight it possible to bank to create an offers to costumer on loan based on their past performances and a good consumer management will be essential (Fuleky, 2020). 
The recent study and report conduct by Marr (2015) suggest that the most important about the big data are not the size of volume nor the characteristic but instead how the company able to make best of it and the affordance towards the firms. In the consumer loans scenario, by setting the parameter to help bank prevent the consumer loans account being default and predicting the trend of consumer loans in the future bank able to create a substantial meaning on their big data analytic

\section{Augment Banking in consumer loans}

Another element of industry 4.0 in this research would like to analyst are the augment banking in consumer loans banking business. To answer the questions first it is better to understand how the augment banking in consumer loans are works. Knowing from previous explanation about the augment reality, it enables mirroring what happen in actual world through the use of computer mirroring into the virtual world. Caudell and Mizell (1992) use a sophisticated word describing augment reality as superimposed of the data process by the computer into the real word.

Costumer using web or mobile applications in financial services are expected the services to be durable, accessible, convenient and engaging. It becomes clear that in order to achieve that level expected service, augment reality can be applied to enhance and leverage the business scenario that being deliver to the costumer or even create a completely new business cases (Pranatharthy et al., 2013). Through the augment reality, costumers are able to access banking service virtually. Augment banking in consumer loans operates in the computer-based program wherein the user can feel and sense detail environment of the consumer loans. Furthermore, enable the user or the potential borrower to access the bank through virtual and able to experience as the same as the real word. In addition, potential borrowers are able to execute the task such as fill and submitted all the important personal information for loans, as well as gathering all the relevant info about the loans.

One particular aspect that can enhance the experience of using consumer loans service is the interactions between costumers and bank. The application of using of augment reality are intended to creating a personal assistant on the web or apps-based service, this personal assistant able to answer all the related questions about the loans and just one-click away from disclose all the important information in which potential borrowers must know and understand before taking a loan.

In addition, one particular real example using the augment reality in the consumer loans industry are the use of chat-robot or chatbot. According to the research conduct by Liu and Lamb (2018) chatbot are the virtual costumer assistant in which able to offer recommendation and explanations to the costumer via text or online web-chat by using the artificial intelligent (Al) construct as the fundamental technology. Chatbot able to deliver diversify of service based on the characteristic of one particular costumer. Therefore, able to match the service with every costumer characteristic and create a personalized service based on the costumer preference. As previously discover that the main ideas of industry 4.0 to be able to serve and deliver the service towards the increasing individualized costumer requirement (Vaidya et al., 2018), chatbot are the one particular tools to carry out in this new form of business. Another advantage when performing the repetitive and monotonous task, chatbot able to perform more efficient and faster compare to human (Shevat, 2017). The use of chatbot also intelligent enough to guide the costumer through the sensitive and disclosure questions more carefully 
than human and also appear to be trustful in costumer eyes, the reason behind are because the chatbot in basic principle are absence of the self-interest (Liu \& Lamb, 2018). Thus, improve the interaction between banks and the costumer. In 2018 an international bank such as Santander, Bank of America, Capital One, Societe Generale and Swedbank been integrate the use of chatbot in their service especially related to the loans (Liu \& Lamb, 2018). Through all the positive explanation ensure the costumer experience richer and more personal, furthermore also enhance the better costumer experience when applying for the loans.

In previous chapter discovers that one of main big main reason consumer loans detriment factor are the costumer's misunderstanding and miss-information about the pre-contractual and contractual of the loans. By using the augment reality, potential borrowers have a better understanding and the loans. Therefore, the likelihood of loans becoming default can be mitigated in order to achieve reduction of consumer loan's detriment.

Efficient and fast process also achievable by using the augment reality, as the creation of virtual banking able to replace the bulk and limited - brick and mortal bank's branch. All the process related to the loans could be done virtually, such as fill and submit the applications. No physical costumer required on the originated loans process and there's no need of the costumer to go to bank when applying loans. This create a service in which deliver a richer experience for the costumer when applying a consumer loans that can be found in the traditional services. The augment reality also able to stimulate engagement between the costumer and bank, when the loans process become more simply encourages more costumers to interaction. What is more from the banks point of view, using augment reality will also make the loans process more efficient and faster. As the assessment and approval of loans applications can be done virtually, business process become more simplified and encourages quick decisions making process. Loan approval can be done virtually without the presence of the manager in the office.

\section{Internet of Things on Consumer Loans}

The next pieces of industry 4.0 component that will be deliberate in this research is the Internet of Things (IoT). It enables to change the way of doing the business. Throughout the use of Internet of things, transforming traditional business to become more intelligent by enable physical asset to be integrated into an intertwined digital and physical process (Lampropoulos et al., 2019). With this interconnection, Internet of things seeks to imbue the everyday environment and it's object linking digitally and allowed "people and devices things to be connected anytime, anywhere with anything and anyone" (Vermessan et al., 2011; Perera et al., 2014). Moreover, internet of things devices that embedded in our everyday surrounding objects' used for creating an autonomous human-like conscious capability in order to make a real-time decision and action without requiring any human involvement, therefore enable the devices to know what to do, what they need, and act accordingly (Khan et al., 2012 ; Perera et al., 2014).

Although in the future development Internet of things applications have possibility to be in every aspect of our daily life (Khan et al., 2012), nowadays the development of Internet of things are still in the early sections. Many researcher already studied the concept and analyze of IoT, its characteristic and the applications sector, one of the research of analyzing the domain of application internet of things have been conducted through various survey by Atzori et al. (2010) in which categorized internet of things applications in the following areas: 
transportations and logistic, healthcare, smart environment domain, personal and social domain, and the futuristic domain. This research is trying to add another domain of internet of things in which in the field of consumer loans business.

The use of Internet of things by bank in consumer loan business would pave the new style connection between bank and the consumer. A special report by The Economist (Herring, 2010) title "augmented business" publish the research by using the internet of things even cow can be monitored. The report describes how the Dutch star-up business create and implant sensor into the ear of the cattle (cow) with the purpose for monitor the cow health, tracking their movement, make sure the cows are healthy, and by the end of the days able to make sure more plentiful supply of meat for people to consume. This approach of using Internet of things also could be applicable in the consumer loans. In consumer loans cases, the consumer itself will be implemented by the sensor and of course it would be impossible to do exactly same as the cow case, but will be using the others devices that already being part of everyday life of the people that is "handphone" or "smartphone". Smartphone are being use as the connected devices, with this allows bank to gathers information on where the consumer go, what are they doing and what they need. The sensor will be attached to the smartphone with the use of banks apps. In the recent day bank apps can be easily found in our smartphone to monitor and take action related to the banking account such as transfer and investment.

When bank complement their banking apps for smartphone with GPS (Global Positioning System) sensor it is a new level of service can be provided. With GPS sensor allow bank to locate where are the user location in real life situation, thus give bank opportunity to mix it with their product and services. Moreover, consumer loans can be leverages into the broader use as well, not only connected to their own sensor but also able to connected to the others sensor in the surrounding areas. For example; when users of bank's apps or costumer entering a mall or their favorite retail market, bank could know immediately and able to notify the users how much money they are able to borrow. In addition to that, another consumer loans offer scenario also could be added with the use of similar mechanism, such as when the users entering travel agency for vacations, when the users are outside the country and all others situation based on the scenario in which bank could imagines when and where are their costumer need the loans most.

With technology behind the internet of things bank able to use it for their advantages, allowing bank to offers product and services in the right time, with sensor embodied everywhere will increase the costumer experience when using bank's service or products. With this method bank also able anticipate the need of costumers through various data collections and sensors and act accordingly. Therefore, bank could offer solution and advises in costumer real-time situation that could help the costumer to make and take right decisions in their financial life. Internet of things become such powerful tools to growing the business in the face of digitalization banking industries.

\section{CONCLUSION}

This research provided the comprehensive and strategic analysis about the implementing the selected elements of the industry 4.0 the consumer loans business, this research also follows the systematic approach to analyses the consumer loans industry. At first this research 
elaborates and explaining the benefactor factor about why the technological advancement in industry 4.0 are important in the consumer loans business, there are two benefactor reason underline why industry 4.0 technological advancement needed are firstly because the high number of detriment in the consumer loans business and secondly coming from the threat of new emerging market of Fintech. From the secondary research identifies that the consumer loans business is one of the highest consumer detriment loss of all the consumer related business in Europe. On the other hand, consumer loans itself also facing the threat from the fintech industries in which started to gain the market share by providing the same services and product but with the technological advancement at their core.

Industry 4.0 itself consist of many technological advancements that able to transform the industry itself. While in the theory there are nine components of industry 4.0, this research selected 3 components in which suitable to apply in the consumer loans banking business.

First is Big data analytic, being able to generate positive outcome for banks with providing bank sharper insight for better understanding the consumers and reducing the consumer loans default by knowing beforehand the risk profile that carry by each and every costumer. The second is augmented banking, driving from the same concept of augment reality in which allowing the consumers to access bank' product and services virtually using the internet and still able to experiences the same way with doing banking in the bank' branch offices. Through the technological behind the augmented banking such as personal assistant and chat-bot, enable banks to provide the costumers with all important answers related to the consumer loans products and services and thus, the likelihood of consumer loans detriment cause by the miss information regarding the consumer loans contract can be reduced. And lastly through the intertwined of digital and physical process and also due to the sensor imbued in the consumer devices, IoT allows bank gather valuable costumers' information, their pattern, preference, and to providing special offers to the right consumer.

Furthermore, because the industry 4.0 are using the technological advancements at their core and the technologies tend to develop fast, the new technological solution or the new way of using the current technologies of industry 4.0 to the consumer loans business could be also applicable as well. Due to the technological development, the remaining industry 4.0 component could also applicable in consumer loans business, for example on the concrete technical point is the use of big data analytic may as well include the social media platform such as Facebook, Instagram and twitter to provide banks more deep knowledge about its costumer. Further studies would recommend on this direction.

\section{REFERENCES}

Adolph, L., Ammon, E., Bausch, U., Beck, S., Bedenberder, H., Bentkus, A., Billmann, M., Braunmandl, A., Brumby, L., Börkircher, M., Clasen, M., Meer, J. D., Diedrich, C., Elmas, F., Epple, U., Focke, G., Fliehe, M., \& Franchi, N. (2018). German Standardization Roadmap Industrie 4.o - Version 3. DKE Deutsche Kommission Elektrotechnik.

Argyres, N. (1996). Evidence on The Role of Firm Capabilities In Vertical Integration Decisions. Strategic Management Journal, 17(2), 129-150. 
https://doi.org/10.1002/(SICI)1097-0266(199602)17:2<129::AID-

SMJ798>3.0.CO;2-H

Armistead, C. \& Rowland, P. (1996). Managing Business Processes: BPR and Beyond. Willey.

Atzori, L., Iera, A., \& Morabito, G. (2010). The Internet of Things: A survey. Computer Networks, 54(15), 2787-2805. https://doi.org/10.1016/j.comnet.2010.05.010

Bolt, W. \& Humphrey, D. (2015). Assessing bank competition for consumer loans. Journal of Banking \& Finance, 61, 127-141. https://doi.org/10.1016/j.jbankfin.2015.09.004

Brown, M., Jappelli, T., \& Pagano, M. (2009). Information sharing and credit: Firm-level evidence from transition countries. Journal of Financial Intermediation, 18(2), 151172. https://doi.org/10.1016/j.jfi.2008.04.002

Caudell, T. P. \& Mizell, D. W. (1992). Augmented reality: an application of heads-up display technology to manual manufacturing processes. In J. F. Nunamaker (Ed.) Proceedings of the Twenty-Fifth Hawaii International Conference on Volume: ii (pp. 659-669). http://dx.doi.org/10.1109/HICSS.1992.183317

Chiang, R. C., Chow, Y. F., \& Liu, M. (2002). Residential Mortgage Lending and Borrower Risk: The Relationship Between Mortgage Spreads and Individual Characteristics. Journal of Real Estate Finance and Economics, 25(1), 5-32. https://doi.org/10.1023/A:1015347516812

Christensen, C. M. (1997). The Innovator's Dilemma - When new Technologies Cause Great Firms to Fail. Harvard Business School Press.

Civic Consulting (2017): Study on measuring consumer detriment in the European Union Final Report, Part 1: Main Report - Study. Directorate-General for Justice and Consumers EU Consumer Programme. https://doi.org/10.2818/87261

Clark, G. (2014). Chapter 5 - The Industrial Revolution. Handbook of Economics Growth 2, 217-262. https://doi.org/10.1016/B978-0-444-53538-2.00005-8

Collin, P. H. (2003). Dictionary of Banking and Finance (3rd ed). Bloomsbury

Evans, D. (2011). The Internet of Things. How the Next Evolutions of the Internet is Changing Everything. Cisco Internet Business Solutions Group (IBSG).

Demsetz, H. (1988). The Theory of the Firm Revisited. The Journal of Law, Economics, \& Organization, 4(1), 141-161. https://doi.org/10.1093/oxfordjournals.jleo.a036941

Dorfleitner, G., Hornuf, L., Schmitt, M., \& Weber, M. (2017). FinTech in Germany. Springer International Publishing.

EBA (European Banking Authority). (2019). EBA Consumer Trend Report 2018/19. https://www.eba.europa.eu/eba-publishes-consumer-trends-report-for-2018-19 
Finlay, S. (2008). The Management of Consumer Credit. Palgrave Macmillan UK.

Financial Services and User Group. (2019). Responsible consumer credit lending - FSUG opinion and recommendations for the review of the consumer credit directive. European Commission. https://ec.europa.eu/info/publications/fsug-opinions2019_en

Fuleky, P. (2020). Macroeconomic Forecasting in the Era of Big Data. Springer International Publishing.

George, G., Osinga, E. C., Lavie, D., \& Scott, B. A. (2016). Big Data and Data Science Methods for Management Research. Academy of Management Journal, 59(5), 1493-1507. https://doi.org/10.5465/amj.2016.4005

Gobble, M. M. (2013). Big Data: The Next Big Thing in Innovation. Research-Technology Management, 56(1), 64-67. https://doi.org/10.5437/08956308X5601005

Gomber, P., Koch, J., \& Siering, M. (2017). Digital Finance and FinTech: current research and future research directions. Journal of Business Economics, 87(5), 537-580. https://doi.org/10.1007/s11573-017-0852-x

Gupta, M. \& George, J. F. (2016). Toward the development of a big data analytics capability. Information \& Management, 53(8), 1049-1064. https://doi.org/10.1016/j.im.2016.07.004

Haddad, C. \& Hornuf, L. (2019). The emergence of the global fintech market: economic and technological determinants. Small Business Economy, 53(1), 81-105. https://doi.org/10.1007/s11187-018-9991-x

He, P., Hua, Z., \& Liu, Z. (2015). A quantification method for the collection effect on consumer term loans. Journal of Banking \& Finance 57, 17-26. https://doi.org/10.1016/j.jbankfin.2015.03.008

International Monetary Fund (2011). Germany: Technical Note on Banking Sector Structure.

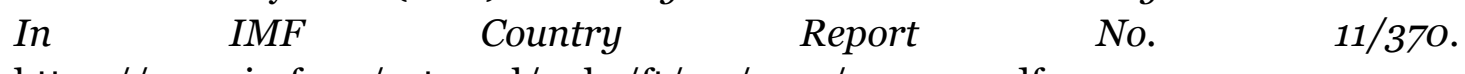
https://www.imf.org/external/pubs/ft/scr/2011/cr11370.pdf

Kagermann, H., Wahlster W., \& Helbi, J. (2013). Recommendations for implementing the strategic initiative INDUSTRIE 4.o. Forschungsunion.

Khan, R., Khan, S. U., Zaheer, R., \& Khan, S. (2012). Future internet: the internet of things architecture, possible applications and key challenges. 2012 1oth International Conference on Frontiers of Information Technology, 257-260. http://dx.doi.org/10.1109/FIT.2012.53

Koch, P., Flötoto, M., Weigl, U., \& Schröck, G. (2016). The road ahead Perspectives on German banking. McKinsey\&Company. 
Kurt, R. (2019). Industry 4.o in Terms of Industrial Relations and Its Impacts on Labour Life. $\begin{array}{llll}\text { Procedia Computer } & \text { Science } & \text { 590-601. }\end{array}$ https://doi.org/10.1016/j.procs.2019.09.093

Lampropoulos, G., Siakas, K., \& Anastasiadis, T. (2019). Internet of Things in the Context of Industry 4.0: An Overview. International Journal of Entrepreneurial Knowledge, 7(1), 4-19. https://doi.org/10.2478/ijek-2019-0001

Liu, A. \& Lamb, G. (2018). Artificial intelligence and augmented intelligence collaboration Regaining trust and confidence in the financial sector. Information \& Communications Technology Law, 27(3), 1-17. http://dx.doi.org/10.1080/13600834.2018.1488659

Lozada, N., Arias-Pérez, J., \& Perdomo-Charry, G. (2019). Big data analytics capability and coinnovation: An empirical study. Heliyon, 5(10), e02541. https://doi.org/10.1016/j.heliyon.2019.e02541

Malhotra, R. \& Malhotra, D. K. (2003). Evaluating consumer loans using neural networks. Omega, 31(2), 83-96. https://doi.org/10.1016/So305-0483(03)ooo16-1

Marr, B. (2015). Big Data: Using SMART Big Data, Analytics and Metrics to Make Better Decisions and Improve Performance. Wiley Hoboken.

Mazibaş, M. \& Tuna, Y. (2017). Understanding the Recent Growth in Consumer Loans and Credit Cards in Emerging Markets: Evidence from Turkey. Emerging Markets Finance and Trade, 53(10), 2333-2346. https://doi.org/10.1080/1540496X.2016.1196895

Milian, E. Z., Spinola, M. d. M., \& Carvalho, M. M. d. (2019). Fintechs: A literature review and research agenda. Electronic Commerce Research and Applications, 34, 100833. https://doi.org/10.1016/j.elerap.2019.100833

Murati, A., Skau, O., \& Taraporevala, Z. (2018). Disruption in European consumer finance: Lesson from Sweden. McKinsey\&Company.

Parlour, C. A. \& Rajan, U. (2001). Competition in Loan Contracts. American Economic Review, 91(5), 1311-1328. https://doi.org/10.1257/aer.91.5.1311

Perera, C., Zaslavsky, A., Christen, P., \& Georgakopoulos, D. (2014). Context Aware Computing for The Internet of Things: A Survey. IEEE Communications Surveys \& Tutorials, 16(1), 414-454. https://doi.org/10.1109/SURV.2013.042313.00197

Porter, M. E. (1998). Competitive Strategy - Techniques for Analyzing Industries and Competitors. The Free Press.

Pranatharthy, A. C., Jaipuriar, A. K., \& Chintalapudi, N. M. (2013). Augment reality in financial service. Infosys. 
Roberts, J. A. \& M Sepulveda, C. J. (1999). Money Attitudes and Compulsive Buying. Journal of International Consumer Marketing, 11(4), 53-74. https://doi.org/10.1300/Jo46v11no4_04

Rüßmann, M., Lorenz, M., Gerbert, P., Waldner, M., Justus, J., Engel, P., \& Harnisch, M. (2015). Industry 4.O: The Future of Productivity and Growth in Manufacturing. The Boston Consulting Group.

Scannella, E. (2015). What drives the disintegration of the loan origination value chain in the banking business. Business Process Management Journal, 21(2), 288-311. https://doi.org/10.1108/BPMJ-02-2014-0017

Schmidt, T. \& Zwick, L. (2018). Loan supply and demand in Germany's three-pillar banking system during the financial crisis. International Finance, 21(1), 23-38. https://doi.org/10.1111/infi.12125

Seddon, J. J. J. M. \& Currie, W. L. (2017). A model for unpacking big data analytics in highfrequency trading. Journal of Business Research, 70, 300-307. https://doi.org/10.1016/j.jbusres.2016.08.003

Shevat, A. (2017). Designing Bots-Creating Conversational Experiences. O'Reilly Media Incorporation

Sivarajah, U., Kamal, M. M., Irani, Z., \& Weerakkody, V. (2017). Critical analysis of Big Data challenges and analytical methods. Journal of Business Research, 70, 263-286. https://doi.org/10.1016/j.jbusres.2016.08.001s

Smullen, J. \& Hand, N. (2005). Oxford dictionary of Finance and Banking (3rd ed). Oxford University Press.

Sonntag, D., Albuquerque, G., Magnor, M., \& Bodensiek, O. (2019). Hybrid learning environments by data-driven augmented reality. Procedia Manufacturing, 31, 32-37. https://doi.org/10.1016/j.promfg.2019.03m.006

Herring, M. (2010, November 6). Augmented Business - Smart system will disrupt lots of industries, and perhaps the entry economy. The Economist Special Report. https://www.economist.com/special-report/2010/11/o6/augmented-business

Tsai, M., Lin, S., Cheng, C., \& Lin, Y. (2009). The consumer loan default predicting model An application of DEA-DA and neural network. Expert Systems with Applications, 36(9), 11682-11690. https://doi.org/10.1016/j.eswa.2009.03.009

Updegrave, W. L. (1987). How Lenders Size You Up One Tip: maintain a checking account. Money, 16(4), 145.

Vaidya, S., Ambad, P., \& Bhosle, S. (2018). Industry 4.0 - A Glimpse. Procedia Manufacturing, 2O, 233-238. https://10.1016/j.promfg.2018.02.034. 
Vasileva, V. (2019). Development of Consumer Lending by Non-Bank Credit Companies in Bulgaria. Economic Archive, 1, 65-77.

Vermessan, O., Friess, P., Guillemin, P., Gusmeroli, S., Sundmaeker, H., Bassi, A., Jubert, I. S., Mazura, M., Harrison, M., Eisenhauer, M., \& Doody, P. (2011). Internet of Things Strategic Research Roadmap. In O. Vermessan \& P. Friess (Eds.), Internet of Things Global Technological and Societal Trends (pp. 9-52). River Publishers. 